Лідер. Еліта.Суспільство
Leader. Elite. Society

УДК 37.035:316.46(100)

doi: 10.20998/2616-3241.2019.1.03

\title{
Василь Галузяк
}

кандидат психологічних наук, доцент, професор кафедри педагогіки і професійної освіти Вінницького державного педагогічного університету імені Михайла

Коцюбинського; Вінниця, Україна

ORCID: 0000-0001-7223-3821

E-mail:wgaluz@gmail.com

\section{Ольга Акімова}

доктор педагогічних наук, професор, завідувач кафедри педагогіки і професійної освіти, Вінницького державного педагогічного університету імені Михайла

Коцюбинського; Вінниця, Україна

ORCID: 0000-0001-6988-6258

E-mail:sopogov@ukr.net

\section{Свген Громов}

кандидат педагогічних наук, старший викладач кафедри педагогіки і професійної освіти

Вінницького державного педагогічного університету імені Михайла Коцюбинського;

Вінниця, Україна

ORCID: 0000-0002-0234-606X

E-mail:vdpu2004@i.ua

\section{СУЧАСНІ ЗАРУБІЖНІ ПІДХОДИ ДО РОЗУМІННЯ ЛІДЕРСТВА І ВИХОВАННЯ ЛІДЕРІВ}

\begin{abstract}
Анотація: розглянуті сучасні зарубіжні підходи до розуміння лідерства та виховання лідерів. 3'ясовано, щзо у сучасній зарубіжній організаційній психології все більшої популярності набувають прогресивні моделі лідерства, які приходять на зміну традиційним центрованим на лідері підходам. Наявність різних поглядів на сутність $i$ призначення лідерства зумовлює існування множинності підходів до виховання лідерів. Виокремлено дві моделі підготовки лідерів - нормативно-адаптивну і особистіснорозвивальну, які відрізняються за своӥми завданнями $і$ способами реалізащії. Кожна модель має свої переваги та обмеження $i$ за певних умов може виявитися ефективною. Загальна стратегія має полягати у тому, щоб з урахуванням конкретних обставин знаходити оптимальний баланс нормативно-адаптивної $і$ особистісно-розвивальної моделей, щңо зробить можливою виховання лідерів нового покоління, здатних не просто керувати підлеглими, а сприяти їх особистісному зростанню, об'єднувати їх навколо спільної мети і надихати на здійснення позитивних змін у суспільстві.
\end{abstract}

(C) Василь Галузяк, Ольга Акімова, Євген Громов, 2019 
Ключові слова: лідер, лідерство, теоріі лідерства, зарубіжні моделі виховання лідерів, нормативно-адаптивна модель, особистісно-розвивальна модель.

\title{
Vasyl Haluziak
}

$\mathrm{PhD}$ in Psychology, Associate Professor, professor at the Department of Pedagogy and Professional Education at Vinnytsia Mykhailo Kotsiubynskyi State Pedagogical

University;

Vinnytsia, Ukraine

E-mail:wgaluz@gmail.com

\section{Olga Akimova}

Dr. Hab. in Pedagogical Science, Professor, Head of the Department of Pedagogy and Professional Education at Vinnytsia Mykhailo Kotsiubynskyi State Pedagogical

University; Vinnytsia, Ukraine

E-mail: sopogov@ukr.net

\section{Ievgen Gromov}

$\mathrm{PhD}$ in Pedagogical Science, Senior Teacher at Department of Pedagogy and Professional Education at Vinnytsia Mykhailo Kotsiubynskyi State Pedagogical University;

Vinnytsia, Ukraine

E-mail:vdpu2004@i.ua

\section{MODERN FOREIGN APPROACHES TO UNDERSTANDING LEADERSHIP AND UPBRINGING LEADERS}

\begin{abstract}
Contemporary foreign approaches to understanding leadership and education and upbringing future leaders have been considered. It's been revealed that in the modern foreign organizational psychology, progressive models of leadership, which replace the traditional leader-centered approaches, are becoming increasingly popular. This transformation is primarily conditioned by transition from industrial to post-industrial paradigm of development, which significantly increases the role of information, intelligence and innovation in all spheres of life. Progressive leadership concepts are characterized by a number of features reflecting changes in interpretation of this complex phenomenon: considering leadership not as an individual influence of a leader on his subordinates, but as a kind of relationship in which an important role is assigned to the leader's followers; transition from competitive transactional leadership to cooperative transformative one; enhancement the leader's educational function. The presence of different views on leadership nature and purpose causes the existence of different approaches to the leaders' education. The analysis of differences in leadership understanding within traditional and progressive concepts enabled to distinguish between two leader training models - normatively-adaptive and personally-developing, differing in their tasks and methods of implementation. Both models have their advantages and limitations and can be effective under certain conditions. Taking into account specific circumstances, the general strategy lies in finding the optimal balance of normatively-adaptive and personally-developing models, making possible upbringing the new generation leaders, who are able not only manage subordinates, but also contribute to their per-
\end{abstract}


sonal growth, bringing them together around common goals, and inspiring for making positive changes in society.

Key words: leader, leadership, theory of leadership, foreign model of education of leaders, normatively-adaptive model, personally-developing model.

\section{Vasyl Haluziak, Olga Akimova, Ievgen Gromov}

An extended abstract of a paper on the subject of:

\section{«Modern Foreign Approaches to Understanding Leadership and Upbringing Leaders»}

Problem setting. In conditions of dynamic socio-cultural development and profound society transformations, connected with active introduction modern information technologies in all spheres of life, requirements for training future specialists are changing. Much attention is paid to upbringing a competitive personality, ready for constant self-improvement, active participation in public life, capable of success and leadership in professional and civic activities. The need for leaders who can effectively operate in transition to the postindustrial society, which significantly increases the role of knowledge, intelligence and innovation in all spheres of life, is very acute. Concepts of leadership training, based on the industrial society realities, are gradually losing their relevance and do not allow effective training young people for leadership in a dynamic and innovative postindustrial environment. It requires finding new approaches to training leaders who meet modern challenges. In this context, considerably interesting is to study the achievements of foreign organizational Psychology and Pedagogy, which both accumulated all wealth of theoretical and practical experience of training leaders, developed numerous leadership concepts and approaches to developing future professionals leadership potential. The most of studies devoted to various aspects of leadership issues was made in the United States. In his fundamental work "Handbook of Leadership» Ralph Stogdill summed up the results of more than five thousand most significant studies [28]. There are several relatively independent areas of leadership theory dealing with various aspects of this problem such as organizational leadership, political, gender, cross-cultural, etc. The American scientists were among the first to realize the need for modernization the process of training leaders in universities, youth and public organizations in connection with the transition to a post-industrial paradigm of social development. Today, foreign Pedagogy has accumulated rich traditions and constructive experience of training leaders, which deserves deep understanding and critical analysis for using it in the process of optimizing the national system of training future professionals for implementation leadership functions in professional and public life. Comprehensive study of foreign leadership concepts and leadership training technologies can help in identifying prospects and potential problems in implementing modern approaches to educating leaders in national higher education system.

Recent researches and publications analysis. The issue leadership education has always been the object of scientific interest for many foreign researchers: J. Burkhart, D. Dey, D. Roberts, J. Rost, P. Shendj, R. Foster, K. Zimmermann-Oster, et al. The innovative approaches to the leaders education are investigated by A. Aston, C. Branhard, K. Kalp, S. Komves, J. Kurtin, C. Townsend, N. Huber et al. A number of dissertations, covering various aspects of future leaders training as well as development of leadership conceptual foundations in modern society, have been recently carried out 
(S. Alain, B. Kelly, D. Clark, D. Kumb, A. Slooter, C. Thompson, D. Frederiks). Identification of leadership competences required for new generation leaders has been made in the works by E. Blackwell, D. Brown, A. Burkham, B. Locke, E. Rowlands, K. Franquier. Other scholars (D. Wagner, D. Roebum, L. Santana, K. Scott, M. Havlik, S. Heinz, etc.) investigated the matter of training leaders in high school. The use of modern pedagogical technologies in the process of training leaders was described in the papers by $R$. Jones, S. Koch, etc. Theoretical foundations and practical ways of training leaders in different western educational systems have been reflected in many pedagogical studies. M. Martynova analyzed the leadership training program for American students in the extracurricular activities. The problem of training leaders in the US student clubs has been considered in the study of I. Ainutdinova [1]. The issue of developing the leadership qualities of American students as a component of their managerial culture has been disclosed by I. Kuznetsova [2]. In dissertation by E. Panfilov the peculiarities of industrial and postindustrial paradigms of leaders' upbringing at the US pedagogical educational establishments have been clarified [4]. O. Ponomarenko also disclosed the basic approaches to formation of leadership qualities in the US educational system [5]. I. Miskov analyzed the school leadership training programs in the UK [3]. E. Saikina reviewed contemporary concepts and trends in student leadership development at the US higher education institutions [6]. Despite the considerable interest of researchers in various aspects of leaders training in foreign pedagogical theory and practice, modern concepts of leadership education have not been sufficiently presented and analyzed in the Ukrainian pedagogical science. Thus there is the need for a comprehensive understanding foreign ideas and approaches that determine the peculiarities of understanding the essence of leadership and leaders training in the $21^{\text {st }}$ century. This will help in overcoming the contradictions between the demands of modern Ukrainian society to the new formation leaders and the theoretical approaches to the leaders training, formed in the previous century.

Paper objective. Leadership education is a very complex and multifactorial process, characterized by variety of approaches to its implementation, and is significantly dependent on social conditions and the general understanding of leadership and its functions at a particular stage of social development. The perceptions of the leader and leadership to a large extent bear the imprint of a particular era and depend on the dominant values and orientations in a certain society. Considering the problem from a historical point of view allows us to highlight a number of common approaches to understanding the leaders and the leadership phenomena that have consistently changed each other. So the article objective is to examine and analyze the contemporary foreign approaches to understanding leadership as well as the process of training leaders capable for meeting the requirements of a post-industrial society.

Paper main body. Historically, the first theories of leadership were based on the idea that leaders are distinguished by certain traits and qualities which other people do not have. Leadership has traditionally been understood as the activity of a leader, whose effectiveness depended primarily on his innate and acquired qualities. Such qualities as intelligence, determination, integrity, communicability, self-confidence, domination were mentioned. Most psychologists and educators believed the myth that leaders only were born and that leadership could not be learned. With the laps of time the theory of leadership has critically evaluated in Psychology and Pedagogy for a number of reasons. After a period of admiration the theories of leadership qualities, a great deal of popularity has been gained in the study of 
leadership skills which can be trained and developed in the learning process. Researchers have become more interested in what leaders do, not what they are. There was a study of leadership styles aimed at identifying effective leadership strategies and to some extent took into account the characteristics of people led by a leader.

New perspective on leadership was proposed in the situational and probabilistic approaches that take into account the peculiarities of the situation and the subordinates in identifying effective leadership strategies. These approaches to understanding leadership are more or less central to a leader's character, since they reduce leadership to: a) leadership characteristics (leadership theories), b) what the leader is able to do (leadership skills), or c) what the leader does (behavior, style, situation). Although these aspects may be useful for understanding the leader's important qualities, skills and behaviors, they set a very narrow perspective on leadership understanding that does not take into account the complexity of the situations in which the leaders act, as well as the significant role of other people - the followers of the leader.

In modern conditions, the so-called progressive models of leadership focus on relative and systemic nature, as well as attach great importance to followers in leadership relations, come to the center of the approaches to leadership. Progressive leadership is characterized by the following basic principles: 1) leadership is a process, not a person or a position; 2) leadership is aimed at forming close relationships in the group and establishing cooperation; 3) leadership is oriented towards achieving positive environmental changes; 4) leadership has a moral and ethical dimension; 5) leadership involves the interrelated levels of the individual, group and system.

Researchers

identified transformational leadership as «process aimed at implementing collective tasks through the mutual use of the motives for achieving planned changes that are present in the leader and followersy. Transformational leadership is to establish a constructive relationship between a leader and followers, so that motivation and moral consciousness as a leader, and those with whom he interacts, rise to a higher level. Such a relationship increases the potential of both parties and contributes to the achievement of joint success. Transformation leadership is opposed to the transactional one, which is based on the exchange operations between the leader and the subordinates. Transactional leadership has the character of the leader's manipulative influence on the subordinates and focused on achievement of situational goals and preservation of the status quo. Unlike the transactional, the transformational leader focuses on establishing long-term relationships with followers, so trying to transform them so that they seek to achieve the highest success in their activities. The transformational leader strives to make subordinates perceive the organization's tasks as their own. This is achieved through four main factors: 1) the charismatic influence of the leader who leads the future, shows the ways of achieving it, gives personal example, sets high standards of activity, demonstrates energy, self-confidence, determination and optimism; 2) intellectual stimulation (inducing subordinates to strategic thinking, creativity, innovation and rational problem solving);

3) inspirational stimulation (suggestion to subordinates enthusiasm and optimistic view of the future); 4) an individual approach to subordinates (respect, careful attitude to subordinates, taking into account their personal interests). Studies have shown that the followers work more productively, focus on achieving higher results, and transformational leaders are valued above both subordinates and management.

Other scholars proposed the concept of «super-leadership». So called «super leader» is the one who contributes to 
formation of self-leadership in subordinates, performing the role of not the director, but the teacher and the educator: he encourages subordinates to set their own goals, experiment, not to be afraid of minor mistakes. If in other theories attention is focused on how the leader manages the subordinates, performing a controlling function, then this concept emphasizes the educational function of the leader, who must teach subordinates to manage themselves.

Another big concern for followers is the concept of "servant-leadership» which presumes that the leader serves to his subordinates. Unlike the traditional views the modern leader should serve people, take care of their needs. The researchers outlined a number of characteristics of the servantleader: desire to serve others; desire to lead; personal growth (in the process of which the leader becomes wiser, more autonomous, free, moral); desire for equal partnership relationships. These ideas have become greatly widespread in the American individualized society in the field of business, government institutions, universities, religious, and non-profit organizations.

Another theory proposed the concept of "leader-trablaiser» - the innovator, discoverer the new activity ways. The researchers outlined 10 metaphors characterizing various aspects of the leader's activity as an innovator: "predecessor» - the one who was the first in time, previously expressed the idea, did something; "pioneer» - the first in space, arrived at a certain place earlier than others; "expert» - has the highest qualification; "authority» possesses considerable knowledge and information; «master» - has highabilities; «superior» - has the greatest power and influence; «senior»-has more experience; "scholar» - the most trained, competent; "inventor» - the developer of the best technology; «innovator» - the creator of the best theory, plan, model. These leaders are in great demand in the modern organization of life.
The analysis of modern foreign leadership concepts enables us to distinguish several characteristic trends that reflect changes in understanding this complex phenomenon: 1) change in understanding leadership - from transactional, competitive, dominant, aggressive, manipulative, selfish to transformational, cooperative, democratic, moral and noble; 2) changing the role of followers - from passive to almost leading position; 3) change of leader's functions from supervisor to educator; 4) change theories of leadership - from leader-centered to centered on followers. According to modern approaches, a leader is considered to be a person who is capable of setting attractive goals and ensuring their adoption and implementation by followers who are personally involved in achieving a common goal. Accordingly, leadership is understood as: 1) the leader's ability, without coercion, to influence the group to achieve a common goal; 2) an influence that encourages subordinates or followers to make every effort to achieve the desired goals;

3) developing relationships with followers, turning them into leaders or agents of change, expanding their capabilities and encouraging them to achieve the highest results in their activities.

Changing views on the nature and purpose of leadership, in turn, leads to a revision of approaches to the education of leaders. The concept of leadership has different content in the approaches centered on the leader, and the concepts of progressive leadership, which changes the tasks and methods of training leaders in the frameworks of each paradigm. In theories of progressive leadership, the leader is an individual who, acting in accordance with the interests and needs of his followers, transforms their value orientations and convictions to ensure their personal growth and the achievement of common good. A leader doesn't control his followers but shares his powers with them, thereby making them leaders. Progressive leadership is not 
an individual influence on subordinates, but the collective process of interactions, in which the leader and the followers are actively involved, on the basis of common values, in order to achieve positive change and realize common tasks.

Taking into account the paradigmatic differences in understanding leadership in the traditional (leader-centered) and progressive approaches, one can distinguish two relevant leadership training models normatively-adaptive and personallydeveloping, which differ in their tasks and methods of implementation.

Within the framework of the normative-adaptive model, leaders are prepared to watch deviations in processes known to them and seek for problems solutions based on generally accepted concepts, theories, and rules. In behavior, they are guided by objective knowledge and normative representations, not trusting their subjective experience. They feel the need for certain abstract theories, models and expert opinions in order to adapt their experience and exercise leadership. As a result the leaders are inclined to operate the categories of past experience, use previously tested behavior strategies and act in accordance with generally accepted leadership standards. They are inclined to make decisions that preserve and maintain the usual leadership practices, without questioning traditional ideas about the correct behavior of the leader. According to this model such leaders are not focused on joint search, continuous training and the introduction of innovations into their activities.

An alternative to normativelyadaptive is the personality-developing model of leaders training which closely meets the requirements of the post-industrial society. Within the framework of this model, the main attention is paid to training successful actors of leadership activities through the development of their perception, thinking, reflection, forming desire for personal growth and increasing leadership effectiveness. The personal development model of training stimulates the critical perception of the individual's leadership behavior, the way of thinking, the acquired skills and abilities, attitudes and stereotypes in order to independently change them and bring them into line with the changing requirements of the environment and the future. Such changes manifest themselves in the general openness of the individuals to innovation, readiness to acquire new knowledge and skills, analyze their behavior and review the usual standards and leadership standards.

The personally-developing model is aimed at training leaders who aren't just engaged in constant self-improvement, but also contribute to the training and selfdevelopment of their followers. Such leaders seek for disclose the capabilities of all participants in leadership relationships, engage them in decision-making and finding effective approaches to problem solving. Expressing their views and suggestions, they also urge others to think about the same problem, take part in a collective search for solutions. Such leaders avoid one-sided influence on subordinates; instead they seek to combine different thoughts and proposals of followers to achieve a common goal. It is this strategy of leadership allows us to succeed in terms of variability, multidimensionality and variability of postindustrial society.

Comparison of the normativelyadaptive and the personally-developing leadership training models does not allow making a definite conclusion about their effectiveness or inefficiency. The adequacy and productivity of both approaches to leadership development depends to a large extent on the tasks that put society in front of the leaders at different stages of their development. The normative-adaptive model, typical for an industrial society, standardizes leadership experience and limits individual deviations in the implementation of leadership. It has a conservative character 
and aims at adapting the individual qualities and ways of leadership to the environment requirements, the allocation and mastering the list of universal leadership competencies. Leadership strategies, formed within the framework of the normative-adaptive model of training, are characterized by a high degree of standardization, automation and are well suited for the implementation in relatively stable and regulated conditions of the industrial society.

The personally-developing leadership training model is typical for the postindustrial society, and enables future leaders to form their readiness to operate effectively, even if they are required to change their understanding leadership, review own ideas of its functions and strategies. This model allows future leaders go beyond the formed stereotypes and critically treat the general ideas of leadership, develop new understanding its essence and ways of implementation. The personally-developing model is aimed at training leaders who are able to effectively perform their functions in a mode of openness, uncertainty, pluralism of thought based on innovative thinking, constant self-improvement and orientation towards the unification of the followers' efforts to achieve a common goal. Due to this, the personally-developing model of leaders training meets the requirements of the post-industrial society.

However, the complete refusal to use the normative-adaptive model of training leaders is hardly possible. This is primarily due to some psychological peculiarities of personality development. Each individual is formed, including at the subconscious level, the so-called implicit theory of leadership the actual understanding of this phenomenon, based on beliefs of traditional society. Such a theory, as a rule, has a conservative, rigorous character, as a result of which any attempt to question it and change the perceived by the individual as an encroachment on his identity. This explains the fear of many leaders to retreat from the usual model of leadership and carry out their activities contrary to generally accepted social norms and standards. In connection with this, implementation of the personality-developing model of leaders training, which involves the rejection of the learned stereotypes and traditional leadership forms, is considerably complicated. Its implementation should be preceded by the normative-adaptive stage in which individuals master the traditional knowledge, skills and strategies of leadership. Critical reflection is possible only at the next stage, through which the individual becomes able to analyze why he is leading one or another way, trying to change the usual way of thinking and behavior, mastering innovative ways of leadership.

It is probable that with the evolution of society, its transition to the post-industrial stage, the personally-developing model of leadership will become dominant, but it is unlikely to completely supplant the regulatory-adaptive model.

Conclusions of the research. The analysis shows that in contemporary foreign organizational psychology, the progressive models of training leaders are gaining popularity. They are gradually replacing the leader-centered approaches. It happens primarily due to the transition from the industrial to post-industrial development paradigm, which significantly increases the role of information, intelligence and innovation in all spheres of life. The progressive leadership conceptions are characterized by a number of features reflecting changes in attitude to this complex phenomenon: consideration leadership as not an individual leader's influence on subordinates, but as a kind of relations, in which an important role belongs to the leader's followers; transition from the competitive transactional leadership to cooperative transformation; enhancement of the leader's educational function. According to modern approaches, a leader is considered to be a person who is capable of 
setting attractive goals and ensuring their adoption and implementation by his followers who are personally involved in achieving a common goal. The presence of different views on the nature and purpose of leadership causes the existence of different approaches to the leaders education and upbringing. The analysis of differences in understanding leadership in the traditional and progressive concepts enabled to distinguish between two leaders training models - the normatively-adaptive and personally-developing, differing in their tasks and methods of implementation. In the normative-adaptive model, the leaders' training is carried out by adapting their features and ways of behavior to their traditional ideas and functions in society. The personally-developing model stimulates critical perception of the leaders' behavior, ways of thinking, acquired skills and abilities, views and stereotypes in order to change them independently and bring them

Постановка проблеми в загальному вигляді та ii зв'язок із важливими науковими чи практичними завданнями. В умовах динамічного соціокультурного розвитку і глибинних перетворень суспільства, пов'язаних 3 активним впровадженням в усі сфери життя сучасних інформаційних технологій, змінюються вимоги до професійної підготовки майбутніх фахівців. Все більше уваги приділяється підготовці конкурентоздатної особистості, готової до постійного самовдосконалення, активної участі в громадському житті, спроможної досягати успіхів і здійснювати лідерство в професійній i громадській діяльності. Дуже гостро відчувається потреба в лідерах, здатних ефективно діяти в умовах переходу до постіндустріального суспільства, в якому суттєво підвищується роль знань, інтелекту й інновацій в усіх сферах життя. Концепції підготовки лідерів, засновані на реаліях in line with the changing requirements of environment in future. Each model has advantages and limitations and can be effective under certain conditions. Under specific circumstances the general strategy should enable finding an optimal balance of the normatively-adaptive and personallydeveloping models that will make possible the training the leaders of new generation who are able not only manage subordinates, but also contribute to their personal growth, bring them together around common goals and inspire them for making positive changes in society.

The prospects for further research may be seen in adaptation foreign ideas of leadership and leaders education and upbringing to the Ukrainian educational realities. Creative use of this experience may be very helpful in the process of training young people for performing leadership functions in professional activities and public life.

індустріального суспільства, у наш час поступово втрачають свою актуальність $\mathrm{i}$ не дозволяють повною мірою підготувати молодих людей до лідерства в динамічному й інноваційному постіндустріальному середовищі. Все це вимагає пошуку нових підходів до підготовки лідерів, які б відповідали сучасним викликам.

У цьому контексті значний інтерес становить вивчення досягнень зарубіжної організаційної психології і педагогіки, в яких накопичений багатий теоретичний i практичний досвід підготовки лідерів, розроблені численні концепції лідерства i підходи до розвитку лідерського потенціалу майбутніх фахівців. Найбільше досліджень, присвячених різним аспектам проблематики лідерства, виконано в США. Ральф Стогдил (Ralph Stogdill) у своїй фундаментальній праці «Керівництво 3 лідерства» узагальнив результати більше п'яти тисяч найбільш значущих досліджень [28]. Сформувалося 
декілька відносно самостійних напрямів теорії лідерства, які розглядають різні аспекти цієї проблеми: організаційне лідерство, політичне, гендерне, кроскультурне тощо.

Американські вчені одними 3 перших усвідомили необхідність модернізації процесу підготовки лідерів в університетах, молодіжних і громадських організаціях у зв'язку 3 переходом до постіндустріальної парадигми суспільного розвитку. На сьогодні зарубіжна педагогіка акумулювала багаті традиції і конструктивний досвід підготовки лідерів, який заслуговує глибокого осмислення і критичного аналізу з метою його використання в процесі оптимізації вітчизняної системи підготовки майбутніх фахівців до виконання лідерських функцій у професійному і громадському житті. Всебічне вивчення зарубіжних концепцій лідерства i технологій підготовки лідерів може допомогти визначити перспективи i потенційні проблеми в процесі впровадження сучасних підходів до виховання лідерів у вітчизняній системі вищої освіти.

Аналіз останніх досліджень i публікацій, у яких започатковано розв'язання цієї проблеми i на які спирається автор. Проблематика лідерства i виховання лідерів є об'єктом наукового інтересу багатьох зарубіжних дослідників: Дж. Буркхарт, Д. Дейя, Д. Робертс, Дж. Рост, П. Сендж, Р. Фостер, К. ЦіммерманОстер та ін. Розробкою інноваційних підходів до виховання лідерів займаються А. Астін, К. Брангард, К. Калп, С. Комівс, Дж. Куртін, К. Таунсенд, Н. Х'юбер та ін.

Протягом останнього часу
виконано низку дисертаційних
досліджень, в яких розглядаються різні
аспекти підготовки майбутніх лідерів:
розробка концептуальних основ лідерства
в сучасному суспільстві (С. Ален,
Б. Келлі, Д. Кларк, Д. Кумб, А. Слотер,
Ч. Томпсон, Д. Фредерікс);

Лідер. Еліта.Суспільство 1'2019 визначення лідерських компетентностей, необхідних новому поколінню лідерів (Е. Блеквел, Д. Браун, А. Буркхам, Б. Локк, Е. Роулендз, К. Франкуер); підготовка лідерів в умовах вищої школи (Д. Вагнер, Д.Розебум, Л. Сантана, К. Скотт, М. Хавлик, С. Хайнз та ін.); застосування сучасних педагогічних технологій у процесі підготовки лідерів (Р. Джоунс, Ш. Коч та ін.).

Так М. Мартинова проаналізувала програми лідерської підготовки американських студентів у процесі позааудиторної діяльності. Проблема підготовки лідерів у студентських клубах США розглянута в дослідженні I. Айнутдінової [1]. Питання розвитку лідерських якостей американських студентів як компонента їх управлінської культури розкриті I. Кузнецовою [2]. У дисертаційному дослідженні Є. Панфілової 3'ясовані особливості індустріальної i постіндустріальної парадигм виховання лідерів у педагогіці США [4]. О. Пономаренко розкрила основні підходи до формування лідерських якостей у системі педагогічної освіти США [5]. І. Миськів проаналізувала програми підготовки шкільних лідерів у Великій Британії [3]. Є. Сайкіна розглянула сучасні концепції $\mathrm{i}$ тенденції розвитку лідерських якостей студентів у закладах вищої освіти США [6]. Однак ще й досі $є$ аспекти, що відкриті для наукових пошуків

\section{Виділення не вирішених раніше} частин загальної проблеми, котрим присвячується дана стаття. Не зважаючи на значний інтерес дослідників до різних аспектів підготовки лідерів у зарубіжній педагогічній теорії i практиці, сучасні концепції виховання лідерів поки що недостатньо представлені і проаналізовані в українській педагогіці. Існує необхідність у цілісному переосмислені зарубіжних ідей i підходів, що визначають особливості розуміння лідерства і підготовки лідерів в умовах XXI століття. Це сприятиме подоланню суперечності між вимогами сучасного 
українського суспільства до лідерів нової формації і теоретичними підходами до їхнього виховання, що сформувалися в попередньому столітті.

Формулювання цілей статті (постановка завдання). Мета нашої статті в узагальненні досвіду щодо сучасних зарубіжних підходів до розуміння лідерства та підготовки лідерів, які відповідають вимогам постіндустріального суспільства.

Виклад основного матеріалу дослідження 3 повним обгрунтуванням отриманих наукових результатів. Виховання лідерів - це складний багатофакторний процес, що відрізняється різноманіттям підходів до його реалізації і суттєво залежить від соціальних умов та загального розуміння лідерства і його функцій на конкретному етапі суспільного розвитку. Уявлення про лідера і лідерство значною мірою несуть на собі відбиток конкретної епохи i залежать від домінуючих в суспільстві ціннісних орієнтацій та загального життєвого устрою. Розгляд проблеми в історичному ракурсі дає змогу виділити ряд загальних підходів до розуміння феноменів лідера i лідерства, що послідовно змінювали один одного.

Історично перші теорії лідерства грунтувалися на ідеї, що лідери відрізняються певними рисами, якостями, яких не мають інші люди. Лідерство традиційно розумілося як активність лідера, ефективність якої залежить передусім від його вроджених і набутих якостей (Флемінг Е., Гербер, Хантер Е., та інш). Серед таких якостей називалися, зокрема, інтелект, рішучість, цілісність, комунікабельність, впевненість у собі, домінування та ін. [21]. Однак теорії лідерських рис критично оцінюються у сучасній організаційній психології через низку причин. По-перше, відсутня однозначність і послідовність у визначенні переліку лідерських рис: різні дослідники виокремлюють різні якості, що значною мірою залежить від їхніх суб'єктивних уявлень про успішного лідера. По-друге, теорії лідерських рис не враховують контексту діяльності лідера й особливостей конкретної ситуації. Водночас риси, які потрібні, щоб бути успішним в одній ситуації або сфері діяльності (наприклад, у бізнесі), можуть відрізнятися від тих, які необхідні, щоб бути успішним в іншій сфері (наприклад, в освіті). Крім того, теорії рис не враховують особливостей інших людей, 3 якими взаємодіє лідер: робота 3 різними людьми може вимагати різних якостей i здібностей. Нарешті, фокусування на лідерстві як функції певних рис особистості, у тому числі вроджених, призводить до песимістичної оцінки можливостей цілеспрямованої підготовки лідерів. Більшість сучасних психологів вважає міфом віру в те, що лідерами народжуються i що лідерства не можна навчитися [19].

Після періоду захоплення теоріями лідерських якостей значної популярності набули дослідження лідерських умінь i навичок, які можуть формуватися й розвиватися у процесі навчання (А. Халпин, Р. Блейк и Дж. Мутон, Р. Танненбауманд, В. Шмидт, П. Сэдлер, Дж. Музиканд, Б. С. Рейманн). Дослідники почали більше цікавитися питанням, що роблять лідери, а не якими вони є. З'явилися дослідження стилів лідерства, що спрямовувалися на визначення ефективних стратегій лідерства і певною мірою враховували особливості людей, яких очолює лідер [19]. Тим не менше, в теоріях лідерських умінь і стилів лідерства центральна роль відводилась лідерові та його поведінці. Взагалі не враховувалася специфіка ситуації або контекст лідерства і лише частково бралися до уваги особливості людей в організації.

Новий погляд на лідерство був запропонований у ситуаційних i ймовірнісних підходах, які враховують особливості ситуації та підлеглих під 
час визначення ефективних стратегій лідерської діяльності (П. Херси, К. Бланшар, Р. Веккио, Ф. Фидлер, В. Вруманд, П. Йеттон).

Всі вище підходи до розуміння лідерства більшою чи меншою мірою мають центрований на лідері характер, оскільки зводять лідерство до: а) характеристик лідера (теорії лідерських рис), б) того, що лідер здатний робити (лідерські вміння), або в) того, що лідер робить (поведінка, стиль, ситуація). Хоча ці аспекти можуть бути корисними для розуміння важливих якостей, умінь i способів поведінки лідера, вони задають дуже вузький ракурс розуміння лідерства, що не враховує складності ситуацій, в яких вони діють, а також значної ролі інших людей - послідовників лідера.

У сучасних умовах на зміну центрованим на лідері підходам приходять «прогресивні моделі» лідерства, які акцентують увагу на його релятивному i системному характері, а також надають важливого значення послідовникам як суб'єктам лідерських відносин.

Прогресивне лідерство характеризується такими основними принципами:

- це процес, а не особистість чи позиція;

- відносини, спрямовані на формування тісних взаємостосунків у групі i налагодження співпраці;

- воно зорієнтоване на досягнення позитивних змін у навколишньому середовищі;

- має морально-етичний вимір;

-охоплює взаємопов'язані рівні індивіда, групи та системи.

На думку теоретиків прогресивного лідерства, саме на основі цих принципів можна впоратися з викликами, які постають перед сучасним суспільством, i досягти реальних, суттєвих і стабільних змін у функціонуванні організацій [17].

Основи прогресивного підходу до розуміння лідерства були закладені Дж. Бернсом (J. Burns), який обгрунтував концепцію трансформаційного лідерства [11].
Дослідник визначив трансформаційне лідерство як «процес, спрямований на реалізацію колективних завдань через взаємне використання мотивів досягнення планованих змін, наявних у лідера i послідовників» [22, c. 82]. Трансформаційне лідерство полягає у налагодженні конструктивних відносин між лідером і послідовниками, завдяки чому мотивація і моральна свідомість як лідера, так і тих, 3 ким він взаємодіє, піднімаються на вищий рівень. Такі відносини підвищують потенціал обох сторін і сприяють досягненню спільного успіху. Трансформаційне лідерство протиставляється Дж. Бернсом транзакційному, яке грунтується на операціях обміну між лідером i підлеглими: наприклад, обмін позитивних і негативних стимулів (зарплата, похвала, покарання тощо), що впливає на якість виконання підлеглими трудових обов'язків. Транзакційне лідерство, зазначає Дж. Бернс, має характер маніпулятивного або директивного впливу лідера на підлеглих і зорієнтоване на досягнення ситуативних цілей i збереження статус-кво.

На відміну від транзакційного, трансформаційний лідер орієнтується на створення довготривалих стосунків 3 послідовниками, тому намагається змінити (трансформувати) їх так, щоб вони прагнули до досягнення найвищих успіхів у діяльності. Послідовник Дж. Бернса і Б. Басс вважає, що трансформаційне лідерство має місце тоді, коли лідер розширює інтереси підлеглих, сприяє усвідомленню і прийняттю ними цілей i завдань групи, пробуджує в них прагнення виходити за межі власних інтересів заради досягнення блага всієї групи [9, с. 21]. Він прагне до того, щоб підлеглі сприймали завдання організації як свої власні. Це досягається за допомогою чотирьох основних чинників: 
1) харизматичний вПлив лідера, який передбачає майбутнє, показує шляхи його досягнення, подає особистий приклад, встановлює високі стандарти діяльності, демонструє енергійність, упевненість у собі, рішучість і оптимізм;

2) інтелектуальна стимуляція (спонукання підлеглих до стратегічного мислення, творчості, інновацій і раціонального вирішення проблем);

3) надихаюче стимулювання (навіювання підлеглим ентузіазму і оптимістичного погляду на майбутнє);

4) індивідуальний підхід до підлеглих (повага, турботливе ставлення до підлеглих, врахування їх особистих інтересів).

Дж. Бернс закликав дослідників i лідерів-практиків вийти за межі традиційного розуміння ролі такої особистості і зосередитися на взаємостосунках між лідером i послідовниками.

Дослідження показали, що команда послідовників працює більш продуктивно, орієнтується на досягнення вищих результатів, а трансформаційні лідери оцінюються вище як підлеглими, так і керівництвом.

Теорія трансформаційного лідерства Дж. Бернса стала основою для виникнення інших прогресивних моделей. Дж. Рост обгрунтував концепцію постіндустріального лідерства i закликав відмовитися від традиційного його розуміння, характерного для індустріальної епохи [24]. У своїй книзі «Лідерство у двадцять першому столітті» (1991) він запропонував визначення лідерства, яке, на його погляд, більше відповідає сучасним життєвим реаліям. На його думку, лідерство - це взаємопов'язані впливи лідера i послідовників, спрямовані на досягнення реальних змін, що відображають їх спільні цілі. Це визначення містить чотири основні компоненти, кожен 3 яких є суттєвим $\mathrm{i}$ повинен бути присутнім, щоб конретні відносини можна було вважати лідерством:

1. Відносини засновані на впливі, який може мати різні напрями (не обов'язково зверху вниз), причому способи впливу не повинні бути примусовими. Лідерські відносини грунтуються не стільки на владі й авторитеті, скільки на переконанні.

2. Лідери та послідовники є суб'єктами відносин. Якщо лідерство визначається як відносини, то і лідери, i послідовники здійснюють його. Йдеться не про те, що всі учасники в цьому рівні, але всі впливають один на одного. Як правило, за такої взаємодії $є$ більше одного послідовника і більше одного лідера.

3. Лідери та послідовники прагнуть досягти реальних змін. Таке прагнення означає, що вони пропагують i цілеспрямовано шукають змін. Реальні зміни, яких прагнуть досягти лідери i послідовники, повинні мати суттєвий характер.

4. Зміни, яких лідери i послідовники прагнуть досягти, відображають їхню спільну мету. Ключовим є те, що бажані зміни повинні відображати не тільки бажання лідера, а й бажання послідовників [24].

Таким чином, Дж. Рост стверджує, що лідерство - це не те, що роблять лідери, а, швидше, те, що лідери i послідовники роблять разом для спільного добра. У сучасному суспільстві лідери можуть бути ефективними лише за умови партнерської взаємодії та об'єднання зусиль 3 послідовниками. Один лідер не має відповідей на всі питання і не взмозі забезпечити реальні зміни. У сучасному світі, стверджує Дж. Рост, багато людей беруть участь у лідерстві: одні - як лідери, інші - як послідовники. Тільки тоді, коли всі працюють спільно, стають можливими успішні зміни заради реалізації єдиної мети. 
Переважна більшість фахівців у галузі організаційної психології погоджуються з тим, що визначення Дж. Роста більше відповідає типу лідерства, необхідного в сучасному суспільстві. Теоретики i практики поступово відмовляються від старих способів лідерства, характерних для індустріальної парадигми. Традиційний підхід до розуміння лідерства грунтується на філософії односпрямованого впливу зверху вниз, коли лідер сприймається як домінуючий, ефективний, неемоційний $\mathrm{i}$ контролюючий. На противагу цьому, постіндустріальна парадигма, характеризується плюралізмом поглядів, розподілом влади, розширенням прав $\mathrm{i}$ можливостей послідовників, емоційною включеністю лідера у стосунки 3 підлеглими.

Трансформаційна теорія лідерства Дж. Бернса і теорія постіндустріального лідерства Дж. Роста заклали фундамент для нового розуміння цієї дефініції, яке приходить на зміну центрованим на лідерові підходам. Наприкінці XX початку XXI століття було розроблено низку гуманістично орієнтованих концепцій лідерства, в яких значна роль відводиться послідовникам як суб'єктам лідерських стосунків.

Ч. Менз і Г. Сіме (С. Manz \& H.Sims) запропонували концепцію «суперлідерства» (super-leadership) [20]. Суперлідер - той, хто сприяє формуванню «само-лідерства» (self-leadership) у підлеглих, виконуючи роль не директора, a вчителя i вихователя: він заохочуе підлеглих ставити власні цілі, експериментувати, не боятися незначних помилок. Якщо в інших теоріях увага фокусується на тому, як лідерові керувати підлеглими, виконуючи контролюючу функцію, то ця концепція наголошує на виховній функції лідера, який повинен навчити підлеглих управляти собою.

Ще більшу турботу про послідовників передбачає розроблена
Р. Гринліфом

(R. K. Greenleaf) концепція сервант-лідерства (servantleadership) - лідерства, обслуговуючого підлеглих [15]. На відміну від традиційного погляду на лідера як керівника, Р. Гринліф вважає, що сучасний лідер повинен служити людям, піклуватися про задоволення їхніх потреб. Дослідник виокремив низку характеристик обслуговуючого лідера: бажання служити іншим; прагнення лідирувати; особистісне зростання (в процесі якого лідер стає мудрішим, більш автономним, вільним, моральним); прагнення до рівноправних, партнерських стосунків. Ідеї Р. Гринліфа набули значного поширення в американському індивідуалізованому суспільстві у сфері бізнесу, державних установах, університетах, релігійних i некомерційних організаціях. Були створені численні програми навчання сервант-лідерства [26].

Дж. Клег (J. Klagge) запропонував концепцію лідера-трейблейзера (traiblaizer) - відкривача нових шляхів i способів діяльності, новатора [18]. Дослідник виокремив десять метафор, які характеризують різні аспекти діяльності лідера як новатора: попередник (predecessor) - той, хто був першим у часі, раніше за всіх висловив певну ідею, щось зробив; піонер (pioneer) - перший у просторі, прибув у певне місце раніше за інших; експерт (expert) - має найвищу кваліфікацію; авторитет (authority) володіє значними знаннями, інформацією; майстер (master) - має високі здібності; начальник (superior) - має найбільшу владу і вплив; старший (senior) - має більший досвід; учений (scholar) - найбільш навчений, компетентний; винахідник (inventor) - розробник кращої технології; новатор (innovator) - творець найкращої теорії, плану, моделі [18]. Дж. Клег акцентує увагу на творчій стороні діяльності лідера, який для того, щоб бути новатором, повинен перебувати у 
постійному творчому пошуку. Саме такі лідери, на думку дослідника, затребувані сучасною організацією життя.

Аналіз сучасних зарубіжних концепцій лідерства дає змогу виокремити декілька характерних тенденцій, що відображають зміни у розумінні цього складного феномену:

- зміна розуміння лідерства - від транзакційного, конкурентного, домінантного, агресивного, маніпулятивного, егоїстичного до трансформаційного, кооперативного, демократичного, морального і благородного;

- зміна ролі послідовників - від пасивної до майже лідерської позиції;

- зміна функцій лідера - від контролюючої до виховної;

- зміна теорій лідерства - від центрованих на лідерові до центрованих на послідовниках.

Згідно 3 сучасними підходами, лідером вважається людина, яка здатна ставити привабливі цілі і забезпечувати їх прийняття та реалізацію послідовниками, котрі відчувають особисту причетність до досягнення спільної мети. Відповідно, лідерство розуміється як:

- здатність лідера, не застосовуючи примусу, впливати на групу для досягнення спільної мети;

- вплив, який стимулює підлеглих або послідовників докладати максимум зусиль для досягнення бажаних цілей;

-розвиток відносин 3 послідовниками, перетворення їх на лідерів або агентів змін, розширення їх можливостей і спонукання до досягнення найвищих результатів у діяльності.

Зміна поглядів на сутність i призначення лідерства, у свою чергу, зумовлює перегляд підходів до виховання лідерів. Досліджуванні поняття мають різний зміст у підходах, центрованих на лідерові i концепціях прогресивного лідерства, у зв'язку з чим змінюються завдання і способи підготовки лідерів у контексті кожної з парадигм.
Традиційно в індустріальному суспільстві лідер сприймається як індивід, що має певні вроджені або набуті соціально затребувані якості, які дають змогу ефективно виконувати лідерські функції. Індустріальне лідерство ієрархічний процес однобічного впливу лідера на підлеглих 3 метою досягнення ззовні заданих цілей, підтримки стабільності й ефективності системи, а також свого домінуючого становища в ній. Таке розуміння терміна визначає відповідну мету підготовки лідерів виховати носія певних соціально затребуваних якостей, знань, умінь i навичок, необхідних для виконання лідерських функцій, пов'язаних 3 керуванням підлеглими i збереженням власного статусу. Основним засобом досягнення цієї мети виступає безпосереднє формування в індивіда нормативно заданого комплексу лідерських компетентностей

особистісних якостей, знань, умінь, стратегій i способів поведінки, які забезпечують успішне виконання лідерських функцій.

У теоріях прогресивного лідерства лідер - це індивід, який, діючи відповідно до інтересів і потреб своїх послідовників, трансформує їхні ціннісні орієнтації та переконання для забезпечення їхнього особистісного зростання й досягнення спільної мети - загального доброботу. Лідер не стільки керує i контролює послідовників, скільки поділяє 3 ними свої повноваження, тим самим роблячи їх лідерами. Прогресивне лідерство - це не індивідуальний вплив на підлеглих, а колективний процес взаємостосунків, в яких беруть активну участь i лідер, i послідовники на основі спільних цінностей 3 метою досягнення позитивних змін і реалізації загальних завдань.

Заснований на ідеях прогресивного лідерства процес підготовки лідерів спрямований на розвиток особистості, здатної надихати послідовників на 
досягнення спільної мети, спроможної ефективно організовувати й координувати колективну діяльність, забезпечувати особистісне зростання всіх іï учасників і реалізацію позитивних змін у динамічному оточенні. При цьому головне завдання полягає не у формуванні в лідера певних якостей, знань, умінь і навичок, а в розвитку його загального особистісного потенціалу, здатності постійно самовдосконалюватися і сприяти особистісному розвитку послідовників 3 метою знаходження нових i ефективних шляхів виконання спільних завдань.

3 огляду на парадигмальні відмінності в розумінні лідерства в традиційних, центрованих на лідерові, i прогресивних підходах, можна говорити про існування двох відповідних моделей підготовки лідерів - нормативноадаптивної і особистісно-розвивальної, які відрізняються за своїми завданнями i способами реалізації.

Формування лідерів у традиційній парадигмі базується на нормативноадаптивній моделі, в рамках якої підготовка ефективного лідера здійснюється шляхом адаптації його характеристик i способів поведінки до існуючих в суспільстві нормативних уявлень про лідера та його функції. При цьому необхідні лідерські уміння формуються на основі вже наявних в індивіда якостей. Досягнуті в результаті цього процесу зміни у знаннях і вміннях індивіда належать до первинних, оскільки привносяться до вже існуючих особистісних диспозицій шляхом їх розвитку і вдосконалення.

Описуючи процес зміни особистісних характеристик лідера шляхом їхньої адаптації до вимог середовища, дослідники звертають увагу на його механістичний і стандартизований характер (С. Агрисис [7], П. Грон [16], Г. Рид[23]). Адаптивне навчання формує в індивіда реактивну поведінку, яка полягає в реагуванні у відповідь на зовнішні стимули. Виховані на основі цієї моделі лідери, як правило, характеризуються пасивністю, схильністю очікувати змін у зовнішньому середовищі і реагувати на них, не докладаючи активних зусиль для зміни загального контексту діяльності. Вони вирішують проблеми, що виникають здебільшого шляхом застосування стандартних процедур, засвоєних знань і умінь, залишаючи без уваги причини виникнення проблем.

У рамках нормативно-адаптивної моделі лідерів готують бачити відхилення у відомих їм процесах і шукати рішення проблем на основі загальноприйнятих концепцій, теорій i правил. У своїй поведінці вони керуються об'єктивними знаннями і нормативними уявленнями, не довіряючи своєму суб'єктивному досвіду. Вони відчувають потребу у певних абстрактних теоріях, моделях i думках експертів для того, щоб адаптувати свій досвід і здійснювати лідерство [27, с. 85]. В результаті такого підходу у лідерів формується схильність оперувати категоріями минулого досвіду, використовувати раніше апробовані стратегії поведінки і діяти відповідно до загальноприйнятих стандартів лідерства. Вони схильні приймати рішення, які зберігають i підтримують звичну практику лідерства, не ставлячи під сумнів традиційні уявлення про правильну поведінку лідера. Згідно 3 результатами досліджень С. Аргирис [7], такі лідери не зоріснтовані на спільний пошук, безперервне навчання i впровадження інновацій у свою діяльність.

Альтернативною відповідно до нормативно-адаптивної $\epsilon$ особистіснорозвивальна модель підготовки лідерів, яка більшою мірою відповідає вимогам постіндустріального суспільства. У рамках цієї моделі головна увага приділяється підготовці успішних суб'єктів лідерської діяльності шляхом розвитку їхнього сприймання, мислення, рефлексії, формування прагнення до 
особистісного зростання і підвищення лідерської ефективності. Особистіснорозвивальна модель підготовки стимулює критичне сприйняття індивідом своєї лідерської поведінки, способу мислення, засвоєних умінь i навичок, поглядів i стереотипів 3 метою їхньої самостійної зміни і приведення у відповідність 3 мінливими вимогами навколишнього середовища і майбутнього. Такі зміни, на думку С. Аргирис [8], П. Сенге [25], П. Карнеріо [12], мають вторинний характер, оскільки проявляються в загальній відкритості індивіда до інновацій, готовності набувати нових знань і вмінь, аналізувати свою поведінку i переглядати звичні норми i стандарти лідерства.

Зміни в мисленні індивіда, які забезпечуються у рамках особистіснорозвивальної моделі, стосуються передусім його самосвідомості, сприйняття себе як лідера. Досить часто люди не бачать себе в ролі лідерів, оскільки сумніваються в наявності у себе лідерських якостей і вважають, що ними народжуються, а не стають. Особистіснорозвивальна модель підготовки дозволяє подолати цей стереотип, оскільки дає змогу кожному індивідові відкрити в собі лідерський потенціал і повірити в себе як самобутнього i рівноправного учасника лідерських стосунків, здатного проявляти ініціативу і робити свій внесок у спільну справу. У рамках цієї моделі майбутні лідери знайомляться 3 існуючими уявленнями про лідерство i критично аналізують традиційні погляди на цей феномен. Виявивши неадекватність і неефективність старих підходів, вони засвоюють нові знання, уміння і навички, генерують нові способи сприйняття й мислення. Завдяки цьому у лідера формується потреба в рефлексивному осмисленні власного досвіду, регулярному перегляді й корекції своїх уявлень про лідерство, безперервному навчанні і постійному пошуку шляхів удосконалення лідерської діяльності.

Особистісно-розвивальна модель спрямована на підготовку лідерів, які не лише займаються постійним самовдосконаленням, але й сприяють навчанню та саморозвитку своїх послідовників. Такі лідери прагнуть розкривати здібності всіх учасників лідерських стосунків, залучають їх до прийняття рішень i пошук ефективних підходів до вирішення проблем. Висловлюючи свої погляди і пропозиції, вони спонукають також інших замислитися над тією ж проблемою, взяти участь у колективному пошуку способів іiі вирішення. Такі лідери уникають однобічного впливу на підлеглих, натомість прагнуть об'єднати різні думки і пропозиції послідовників для досягнення спільної мети. Саме така стратегія лідерства, на думку П. Сенге [25], Грон П., Салас Е. [14], Дафт Р. [13], дозволяє досягти успіху в умовах варіативності, багатоаспектності i мінливості постіндустріального суспільства.

Порівняння

характеристик нормативно-адаптивної і особистіснорозвивальної моделей підготовки лідерів не дозволяе зробити однозначного висновку щодо їхньої ефективності або неефективності. Адекватність i продуктивність обох підходів до підготовки лідерів значною мірою залежить від завдань, які ставить суспільство перед лідерами на різних етапах свого розвитку. Нормативноадаптивна модель, характерна для індустріального суспільства, стандартизує лідерський досвід i обмежує індивідуальні відхилення в здійсненні лідерства. Вона має консервативний характер i спрямована на адаптацію індивідуальних якостей i способів лідерської діяльності до вимог оточення, виділення і засвоєння переліку універсальних лідерських компетентностей. Стратегії лідерства, сформовані у 
рамках нормативно-адаптивної моделі підготовки, характеризуються високою мірою стандартизованості, автоматизованості і добре підходять для реалізації лідером функцій управління і контролю у відносно стабільних і регламентованих умовах індустріального суспільства.

Адаптація, як правило, полягає в удосконаленні вже наявних у індивіда лідерських умінь і якостей, внаслідок чого його становлення як лідера обмежується рамками сформованих особистісних диспозицій i засвоєних моделей поведінки. Орієнтація на загальновідомі і загальноприйняті концепції й уявлення про лідерство приводить до обмеженості лідерського досвіду i недостатньої готовності до діяльності в непередбачуваних умовах сучасного суспільства, що постійно змінюється. Підготовлені у рамках нормативно-адаптивної моделі лідери, як правило, не прагнуть до освоєння інноваційних стратегій i технологій лідерства, негативно ставляться до альтернативних підходів i не здатні осмислити широкий контекст лідерства, який визначається глобальними змінами у суспільному житті.

Особистісно-розвивальна модель підготовки лідерів, характерна для постіндустріального суспільства, дозволяє сформувати у майбутніх лідерів готовність здійснювати свою діяльність ефективно, навіть якщо для цього вимагається змінити своє розуміння цього поняття, переглянути власні уявлення про функції і стратегії лідерської діяльності. Ця модель дозволяє майбутнім лідерам вийти за рамки сформованих стереотипів i критично поставитися до загальноприйнятих уявлень про лідерство, виробити нове розуміння його сутності і способів здійснення. Особистісно-розвивальна модель спрямована на підготовку лідерів, здатних ефективно виконувати свої функції в режимі відкритості, невизначеності, плюралізму думок на основі інноваційного мислення, постійного самовдосконалення й орієнтації на об'єднання зусиль послідовників для досягнення спільної мети. Завдяки цьому особистісно-розвивальна модель підготовки лідерів більшою мірою відповідає вимогам постіндустріального суспільства.

Проте повна відмова від використання нормативно-адаптивної моделі підготовки лідерів навряд чи можлива. Це пов'язано передусім з деякими психологічними особливостями становлення особистості. У кожного індивіда формується, зокрема на підсвідомому рівні, так звана імпліцитна теорія лідерства - власне розуміння цього феномену, засноване на традиційних для конкретного суспільства уявленнях. Така теорія, як правило, має консервативний, ригідний характер, внаслідок чого будь-яка спроба поставити іiі під сумнів і змінити сприймається індивідом як зазіхання на його ідентичність. На думку науковців страх багатьох лідерів відступити від звичної моделі лідерства і здійснювати свою діяльність всупереч загальноприйнятим соціальним нормам i стандартам. У зв'язку з цим значно ускладнюється реалізація особистіснорозвивальної моделі підготовки лідерів, яка передбачає відмову від засвоєних стереотипів і традиційних форм лідерства. Iї̈ впровадженню повинна передувати нормативно-адаптивна стадія, під час якої індивіди опановують традиційні знання, вміння і стратегії лідерства. Тільки на наступній стадії можлива критична рефлексія, завдяки якій індивід стає здатним аналізувати, чому він здійснює лідерство так, а не інакше і намагається змінити звичний спосіб мислення та поведінки, оволодіти інноваційними способами лідерської діяльності.

Ймовірно, що у міру еволюції суспільства, його переходу до постіндустріальної стадії, особистісно- 
розвивальна модель лідерства ставатиме домінуючою, але навряд чи повністю витіснить нормативно-адаптивну модель.

Висновки 3 даного дослідження та перспективи подальших розвідок у даному напрямку. Проведений аналіз свідчить, що у сучасній зарубіжній організаційній психології все більшої популярності набувають прогресивні моделі лідерства, які приходять на зміну центрованим на лідері підходам. Це зумовлено перехлодом до інформаційного суспільства, в якій суттєво підвищується роль інформації, інтелекту й інновацій в усіх сферах життя.

Прогресивним

концепціям лідерства властива низка характерних ознак, що відображають зміни у трактуванні цього складного феномену: розгляд лідерства не як індивідуального впливу лідера на підлеглих, а як лідерських стосунків, в яких важлива роль відводиться послідовникам лідера; перехід від конкурентного транзакційного лідерства до кооперативного трансформаційного; посилення виховної функції лідера. Згідно 3 сучасними підходами, лідером вважається людина, яка здатна ставити привабливі цілі i забезпечувати їхнє прийняття та реалізацію послідовниками, котрі відчувають особисту причетність до досягнення спільної мети.

Наявність різних поглядів на сутність i призначення лідерства зумовлює існування різних підходів до виховання лідерів. Аналіз відмінностей у розумінні лідерства в традиційних i прогресивних концепціях дав змогу

\section{Список літератури}

1. Айнутдинова, И. Н. (2004) Студенческие клубы учащейся молодежи в США как фактор их социального воспитания: автореф. дисс. на соискание учен. степени канд. пед. наук; спец. 13.00.01.Общая педагогика, история педагогики и образования. Казань. 24 с. виокремити дві моделі підготовки лідерів - нормативно-адаптивну і особистіснорозвивальну, які відрізняються за своїми завданнями i способами реалізації. У нормативно-адаптивній моделі підготовка лідера здійснюється шляхом адаптації його характеристик і способів поведінки до існуючих в суспільстві традиційних уявлень про лідера та його функції. Особистісно-розвивальна модель підготовки стимулює критичне сприйняття лідером своєї поведінки, способу мислення, засвоєних умінь i навичок, поглядів і стереотипів 3 метою їхньої самостійної зміни і приведення у відповідність до мінливих вимог навколишнього середовища i майбутнього. Кожна модель має свої переваги та обмеження і за певних умов може виявитися ефективною. Загальна стратегія має полягати у тому, щоб 3 знаходити оптимальний баланс нормативно-адаптивної і особистіснорозвивальної моделей, що зробить можливою підготовку лідерів нового покоління, здатних не просто керувати підлеглими, а сприяти їхньому особистісному зростанню, об'єднувати їх навколо спільної мети і надихати на здійснення позитивних змін у суспільстві.

Перспективи подальших досліджень вбачаємо в адаптації зарубіжних концепцій лідерства та виховання лідерів до українських реалій $\mathrm{i}$ творчому використанні зарубіжного досвіду у процесі підготовки молоді до виконання лідерських функцій у професійній діяльності та суспільному житті.

2. Кузнецова, И. А. (2006) Зарубежный опыт как основа технологии эффективного формирования управленческой культуры студентов - будущих педагогов: автореф. дисс. на соискание учен.степени канд. пед. наук; спец.

13.00.01. Общая педагогика, история педагогики и образования. Ижевск. 20 с. 
3. Миськів, I. С. (2009) Розвиток шкільного лідерства у Великій Британії: автореф. дис. на здобуття наук. ступеня канд. пед. наук;спец. 13.00.01. Загальна педагогіка та історія педагогіки. Дрогобич. 20 с.

4. Панфилова, Е. А. (2012) Индустриальная и постиндустриальная парадигмы воспитания лидеров в педагогике США: автореф. дисс. на соискание учен.степени канд. пед. наук; спец. 13.00.01. Общая педагогика, история педагогики и образования. Смоленск. 24 с.

5. Пономаренко, О. В. (2012) Проблема формування лідерських якостей у педагогічній освіті США: автореф. дис. на здобуття наук. ступеня канд. пед. наук; спец. 13.00.01. Загальна педагогіка та історія педагогіки. Чернігів. 20 с.
6. Сайкина,
Е.И.

(2004)

Современные концепции и тенденции развития лидерских качеств студентов в вузах США: автореф. дисс. на соискание учен.степени канд. пед. наук; спец.

13.00.01. Общая педагогика, история педагогики и образования. Казань. 24 с.

7. Argyris, C. (1985) Strategy, Change and Defensive Routines. MA: Pitman. 386 p.

8. Argyris, C. (1993) Education for leading-learning. Organizational Dynamics. Vol. 21. № 3. P. 5-17.

9. Bass, B. M. (1990) From transcendent to transformational leadership: Learning to share the vision. Organizational Dynamics, №3, 19 - 31 .

10. Bruner, J. (1996) The Culture of Education. Cambridge, Mass.: Harvard University Press. 224 p.

11. Burns, J. M. (1978) Leadership. New York: Harper \& Row. 530 p.

12. Carneiro, P. R. (2000) The Quest for a New Learning Paradigm. Unicorn: Journal of the Australian College of Education. № 26 (3). P. 26-33.
13. Daft, R. L. (2007) The leadership experience. Cincinnati, Ohio: South-Western College Pub. 528 p.

14. Day, D., \& Gronn, P. C., Salas, E. (2004) Leadership capacity in teams. The Leadership Quarterly. № 15 (6). P. 857-880.

15. Greenleaf, R. K. (1997) The servant as leader. In R. P. Vecchio (Ed.), Leadership: Understanding the dynamics of power and influence in organizations.Notre Dame, IN, US: University of Notre Dame Press. Pp. $429-438$.

16. Gronn, P. C. (2003) The New Work of Educational Leaders: Changing Leadership Practice in an Era of School Reform. London: Paul Chapman Publishing. $176 \mathrm{p}$.

17. Heifetz, R. A., \& Linsky, M., Grashow, A. (2009) The Practice of Adaptive Leadership: Tools and Tactics for Changing Your Organization and the World. Boston. Massachusetts: Harvard Business Press. 352 p.

18. Klagge, J. (1996) Defining, discovering and developing personal leadership in organizations. Leadership and organization development journal. Vol. 17.

№ 5. P. 38 - 45 .

19. Komives, S. R., \& Lucas, N., McMahon, T. R. (2013) Exploring leadership: for college students who want to make a difference (3rd ed.). San Francisco: John Wiley \& Sons. 608p.

20. Manz, Ch. C., \& Sims, H. P. (2001) The New Superleadership: Leading Others to Lead Themselves. San Francisco: Berrett-Koehler Publishers 272 p.

21. Northouse, P. G. (2013) Leadership: theory and practice (6th ed.). Thousand Oaks, CA, US, Sage Publications, Inc. 485 p.

22. Pawar, B. S., \& Eastman, K. K. (1997) The nature and implications of contextual influences on transformational leadership: A conceptual examination. Academy of Management Review, 22 (1), 80-109. 
23. Reed, G. (2004) Map pingtheroute of leadership education: caution ahead. PARAMETERS. Vol. XXXIV. № 3. P. $46-60$.

24. Rost, J. C. (1991) Leadership for the Twenty-first Century. Westport: Praeger Publishers. $220 \mathrm{p}$.

25. Senge, P. M. (1990) The fifth discipline: the art and practice of the learning organization. London: Random House. 424 p.

\section{References \\ 1. Ainutdiniva I.N. \\ (2004) Studencheskiye kluby uchashcheysya molodezhi v SSHA kak faktor ikh sotsial'nogo vospitaniya. [Young students clubs as a factor of their social education]. Obshhaja pedagogika, istorija pedagogiki i obrazovanija.} Kazan, 20 p. [in Russian].

\section{Kuznetsova}

I.A.

(2006)

Zarubezhnyy opyt kak osnova tekhnologii effektivnogo formirovaniya upravlencheskoy kul'tury studentov - budushchikh pedagogov. [Foreign experience as a basis of technology for the effective formation of management culture of students - future teachers]. Obshhaja pedagogika, istorija pedagogiki i obrazovanija. Izhevsk, 20 p. [in Russian].

3. Myskiv I.S. (2009) Rozvytok shkilnoho liderstva u Velykiy Brytaniyi. [Development of school leadership in the UK]. Zahal'na pedahohika ta istoriia pedahohiky.. Drohobych, 20 p. [in Ukrainian].

$$
\text { 4. Panfilova E.A. }
$$

Industrialnaya $i$ postindustrialnaya paradigmy vospitaniya liderov $v$ pedagogike SSHA. [Industrial and post-industrial paradigms of educating leaders in the US pedagogy]. Obshhaja pedagogika, istorija pedagogiki i obrazovanija. Smolensk, 24 p. [in Russian].

$$
\text { 5. Ponomarenko O.V. }
$$

Problema formuvannya liderskykh yakostey $u$ pedahohichniy osviti SSHA. [Problem of forming the leadership qualities in the US pedagogical education]. Zahal'na pedahohika
26. Spears, L. (1996) Reflections on

Robert K. Greenleaf and servant-leadership. Leadership and organization development journal. Vol. 17. № 7. P. 33 - 35.

27. Steiner, C. J., \& Gaskin, P. (1998) Educating leaders: From the abstract and rational to the concrete and personal. The Journal of Leadership Studies. № 5 (2). P. $83-102$.

28. Stogdill, R. M. (1974) Handbook of leadership. N. Y.,L.:Free Press, 613 p. ta istoriia pedahohiky. Chernigiv, 20 p. [in Ukrainian].

6. Saykina E.I. (2004) Sovremennyye kontseptsii $i$ tendentsii razvitiya liderskikh kachestv studentov $v$ vuzakh SSHA. [Modern conceptions and tendencies in development students' leadership qualities in the US higher schools]. Obshhaja pedagogika, istorija pedagogiki i obrazovanija. Kazan, 24 p. [in Russian].

7. Argyris, C. (1985) Strategy, Change and Defensive Routines. MA: Pitman. 386 p.

8. Argyris, C. (1993) Education for leading-learning. Organizational Dynamics. Vol. 21. № 3. P. 5 - 17.

9. Bass, B. M. (1990) From transcendent to transformational leadership: Learning to share the vision. Organizational Dynamics. № 3. P. 19 - 31 .

10. Bruner, J. (1996) The Culture of Education. Cambridge, Mass.: Harvard University Press. 224 p.

11. Burns, J. M. (1978) Leadership. New York: Harper \& Row. 530 p.

12. Carneiro, P. R. (2000) The Quest for a New Learning Paradigm. Unicorn: Journal of the Australian College of Education. № 26 (3). P. 26 - 33.

13. Daft, R. L. (2007) The leadership experience. Cincinnati, Ohio: South-Western College Pub. 528 p.

14. Day, D., \& Gronn, P. C., Salas, E. (2004) Leadership capacity in teams. The Leadership Quarterly. № 15 (6). P. 857 - 880. 
15. Greenleaf, R. K., \& Vecchio R. P. (1997) The servant as leader. Leadership: Understanding the dynamics of power and influence in organizations Notre Dame, IN, US: University of Notre Dame Press. P. $429-438$.

16. Gronn, P. C. (2003) The New Work of Educational Leaders: Changing Leadership Practice in an Era of School Reform. London: Paul Chapman Publishing. 176 p.

17. Heifetz, R. A., \& Linsky, M., Grashow, A. (2009) The Practice of Adaptive Leadership: Tools and Tactics for Changing Your Organization and the World. Boston. Massachusetts: Harvard Business Press. 352 p.

18. Klagge, J. (1996) Defining, discovering and developing personal leadership in organizations. Leadership and organization development journal. Vol. 17. № 5 . P. $38-45$.

19. Komives, S. R., \& Lucas, N., McMahon, T. R. (2013) Exploring leadership: for college students who want to make a difference (3rd ed.). San Francisco: John Wiley \& Sons. 608 p.

20. Manz, Ch. C., \& Sims, H. P. (2001) The New Superleadership: Leading Others to Lead Themselves. San Francisco: Berrett-Koehler Publishers. 272 p.
21. Northouse, P. G. (2013) Leadership: theory and practice (6th ed.). Thousand Oaks, CA, US, Sage Publications, Inc. 485 p.

22. Pawar, B. S., \& Eastman, K. K. (1997) The nature and implications of contextual influences on transformational leadership: A conceptual examination. Academy of Management Review. 22 (1). P. $80-109$.

23. Reed, G. (2004) Mapping the route of leadership education: caution ahead. PARAMETERS. Vol. XXXIV. № 3. P. $46-60$.

24. Rost, J. C. (1991) Leadership for the Twenty-first Century. Westport: Praeger Publishers. 220 p.

25. Senge, P. M. (1990) The fifth discipline: the art and practice of the learning organization. London: Random House. 424 p.

26. Spears, L. (1996) Reflections on Robert K. Greenleaf and servant-leadership. Leadership and organization development journal. Vol. 17. № 7. P. $33-35$.

27. Steiner, C. J., \& Gaskin, P. (1998) Educating leaders: From the abstract and rational to the concrete and personal. The Journal of Leadership Studies. № 5 (2). P. 83 - 102.

28. Stogdill, R. M. (1974) Handbook of leadership. N. Y., L.: Free Press, 1974. 613 p.

Стаття надійшла до редколегї 29.01.2019 